\title{
Molecular epidemiology of Vibrio cholerae 01 isolates from Colombia
}

\author{
M. TAMAYO, S. KOBLAVI*, F. GRIMONT*, E. CASTAÑEDA and P. A. D. GRIMONT* \\ Instituto Nacional de Salud, Avenida Eldorado carrera 50 Zona 6, Santafé de Bogota, Colombia and * Unité des \\ Entérobacteries, Unité INSERM 389, Institut Pasteur, 28 rue du Dr Roux, 75724 Paris Cedex 15, France
}

\begin{abstract}
A total of 173 Vibrio cholerae $\mathrm{O} 1$ isolates from the recent cholera epidemic in Colombia was analysed by the polymerase chain reaction (PCR) for the genes encoding the $A$ subunit of cholera toxin $(\operatorname{ctx} A)$ and the zonula occludens toxin (zot), and by ribotyping. All isolates were positive for $c t x A$ and $z o t$, which was confirmed by hybridisation. Ribotyping with restriction endonuclease $B g I I$ digestion of total DNA revealed three ribotypes: B5a comprising $165(96.4 \%)$ isolates, and two new designated ribotypes B20 and B21a in six $(3.5 \%)$ isolates and two $(1.1 \%)$ isolates, respectively. These findings have significant public health implications.
\end{abstract}

\section{Introduction}

At the end of January 1991, cholera appeared in Peru, South America [1]. Two months later, on $10 \mathrm{March}$, the first case of cholera in Colombia was bacteriologically diagnosed in Tumaco, department of Nariño [2-4]. The dissemination of the disease throughout the whole country was always likely because Colombia is a developing country with deficiencies in drinking water supply and sewage treatment. Four years after the emergence of the disease, 31682 cases had been reported [5]. As conventional epidemiological tools for Vibrio cholerae are poor, molecular approaches are essential in documenting the spread of cholera. Grimont and Grimont [6] proposed a quasi-universal typing method based on rRNA gene restriction patterns. This method later became known as ribotyping [7], and was applied for the first time to $V$. cholerae by Koblavi et al. [8], with endonuclease $B g l$ I for DNA cleavage. The ribotyping system of Koblavi et al. [8], applied to 89 isolates, described 17 ribotypes designated B1-B17. This approach was later used by Popovic et al. [9], with different nomenclature. This technique has now been applied to 591 isolates and 54 ribotypes are recognised [10].

$V$ cholerae produces a thermolabile enterotoxin, cholerae toxin (CT), with a mol.wt of $c .85 \mathrm{kDa}$ which is made up of two subunits, A and B. It also produces a toxigenic factor that increases the per-

Received 15 March 1996; revised version accepted 25 Nov. 1996.

Corresponding author: Dr P. A. D. Grimont. meability of rabbit ileal mucosa by affecting the structure of the intercellular tight junction (zonula occludens). The gene for the zonula occludens toxin (zot) is located immediately upstream of the ctx operon encoding CT [11] on a $4.5-\mathrm{kb}$ region termed 'core region'. On the remaining portion of this region is the gene of a third toxin, ace (accessory cholera enterotoxin), that causes fluid secretion in ligated rabbit ileal loops [12].

Fields et al. [13] described polymerase chain reaction (PCR) amplification of a 564-bp fragment of the CT subunit A gene $(\operatorname{ctx} A)$. Based on the published sequence of $z o t$ [14], a primer for the amplification of a 1083-bp fragment of zot has been determined. The present study characterised $173 \mathrm{~V}$. cholerae $\mathrm{O} 1$ isolates from the recent cholera epidemic in Colombia by ribotyping and PCR detection of genes ctx and zot.

\section{Materials and methods}

\section{Bacterial strains}

All of the $V$. cholerae $\mathrm{O} 1$ isolates were isolated during the epidemic (1991-1994); 165 were from faecal specimens from patients with cholera and eight from the environment. All isolates were confirmed as $V$. cholerae $\mathrm{O} 1$ by the oxidase test (Merck) and the string test, performed on a glass microscope slide by suspending one colony in a drop of aqueous sodium deoxycholate $0.5 \%$ [15] and by agglutination with polyvalent anti-Inaba and anti-Ogawa antisera (Difco). Additionally, all isolates were identified biochemically [15] and the biotype was determined by sensitivity to polymixin $\mathrm{B}(50 \mathrm{U})$, agglutination of goat erythrocytes, 
and bacteriophage IV susceptibility. Only 78 isolates were examined for CT by latex agglutination (VETRPLA, Oxoid) and ELISA with a monoclonal antibody (LT39) $[16,17]$.

\section{DNA extraction}

Isolates were grown on Tryptocaseinsoya (TCS) Agar (Diagnostics Pasteur, Marnes-la-Coquette, France) incubated at $37^{\circ} \mathrm{C}$ for $18 \mathrm{~h}$. A single colony was inoculated into $10 \mathrm{ml}$ of TCS broth and agitated for $18 \mathrm{~h}$ at $37^{\circ} \mathrm{C}$. The culture was then centrifuged at $10000 \mathrm{rpm}$ for $10 \mathrm{~min}$. The cells were lysed in buffer containing $0.1 \mathrm{M} \mathrm{NaCl}, 50 \mathrm{mM}$ EDTA.2Na, and 0.1 Tris- $\mathrm{HCl}, \mathrm{pH} 8.0$, supplemented with sodium dodecylsulphate (SDS) $0.5 \% \mathrm{w} / \mathrm{v}$ and proteinase $\mathrm{K}$ (Sigma) $0.5 \mathrm{mg} / \mathrm{ml}$. DNA was extracted with the AutoGen 540 system (AutoGen Instruments, Bioclear, Potterne).

\section{Gene amplification}

The PCR technique was carried out in $0.5-\mathrm{ml}$ microcentrifuge tubes, with $50 \mu$ of reaction mixture consisting of sterile water $35 \mu \mathrm{l}, 10 \times \mathrm{Taq}$ polymerase buffer $5 \mu \mathrm{l}, 200 \mu \mathrm{M}$ deoxyribonucleotide phosphate (dNTP), 50 pmol of each primer (ctx 2 and ctx 3) [12], Taq polymerase (Amersham International, Amersham) 2.5 units and template $1 \mu \mathrm{l}$. The solution was overlaid with one drop of mineral oil (Sigma) before being place in a thermocycler (PTC-100; MJ Research, Watertown, MA, USA). The cycling conditions were as follows: pre-incubation at $94^{\circ} \mathrm{C}$ for $5 \mathrm{~min}, 35$ cycles of $1 \mathrm{~min}$ at $94^{\circ} \mathrm{C}$ for denaturation, $1 \mathrm{~min}$ at $64^{\circ} \mathrm{C}$ for annealing, $2 \mathrm{~min}$ at $72^{\circ} \mathrm{C}$ for elongation, and a final incubation at $72^{\circ} \mathrm{C}$ for $3 \mathrm{~min}$ for the last elongation. The amplicons were electrophoresed through agarose $0.8 \%$ gel (Appligene, Illkirch, France), stained with ethidium bromide, and photographed under UV exposure. A negative control, consisting of the reaction mixture containing distilled water and all other reagents but no template; was included. Control strains were $V$. cholerae 010395 (positive for CT), a heat labile enterotoxin-positive strain of Escherichia coli and a CT-negative strain of non-O1 $V$. cholerae (strain
CIP 63.41). The size of the amplified fragment was $564 \mathrm{bp}$.

PCR amplification of zot was done under the same conditions as above except that primers ZOT 1 and ZOT 2 (Table 1) were used. The expected size of the amplified fragment was $1083 \mathrm{bp}$. Each PCR product was confirmed by hybridisation after transfer on charged nylon membrane (Hybond $\mathrm{N}+$, Amersham International). Digoxigenin-11-dUTP-labelled probes (DIG-Oligotailing kit, Boehringer, Mannheim, Germany) CT int (for $\operatorname{ctx} A$ ) and ZOT 4 (for zot) are detailed in Table 1 .

\section{Ribotyping}

Bacterial DNA was cleaved by restriction endonuclease $B g l$ I (Gibco, Bethesda Research Laboratory, CergyPontoise, France) $10 \mathrm{U} / \mu 1$ at $37^{\circ} \mathrm{C}$ for at least $4 \mathrm{~h}$. Restriction fragments were separated by electrophoresis in agarose $0.8 \%$ gel in Tris borate buffer for $16 \mathrm{~h}$ at $1.5 \mathrm{~V} / \mathrm{cm}$. Restriction fragments of Citrobacter koseri strain 32 generated by $M l u \mathrm{I}$ cleavage $16 \mathrm{U} / \mu \mathrm{l}$; (Pharmacia, Saint-Quentin-en-Yvelines, France) were used as mol. wt marker [18]. The DNA fragments were transfered to nylon membranes (Hybond N, Amersham) by the VacuGene system (Pharmacia). The membranes were fixed at $80^{\circ} \mathrm{C}$ for $15 \mathrm{~min}$. They were hybridised with acetylaminofluorene (AAF)-labelled rRNA from $E$. coli (Eurogentec, Seraing, Belgium). The prehybridisation and hybridisation steps were carried out at $60^{\circ} \mathrm{C}$ for 1 and $16 \mathrm{~h}$, respectively. Post-hybridisation washes were according to the manufacter's instructions.

Digitalisation and interpretation of ribotypes were done with the Taxotron ${ }^{\circledR}$ software package (Taxolab, Institut Pasteur, Paris, France). The membranes were first scanned by One-Scanner (Apple Computers, Cupertino, CA, USA) and the TIFF image obtained was searched for lanes and bands by RestrictoScan ${ }^{\circledR}$ (Institut Pasteur). Fragments sizes were interpolated from migration data by RestrictoTyper ${ }^{\circledR}$ (Institut Pasteur). Automatic identification of ribotypes was done from our laboratory database.

Table 1. Base sequences, positions and references of primers used for amplification of $\operatorname{ctxA}$ and $z o t$

\begin{tabular}{lcc}
\hline Oligonucleotide sequence $\left(5^{\prime}-3^{\prime}\right.$ ends) & Position & Reference \\
\hline ctxA PCR & & \\
ctx 2: CGG GCA GAT TCT AGA CCT CCT G & $73-94$ & {$[13]$} \\
ctx 3: CGA TGA TCT TGG AGC ATT CCC AC & $614-636$ & {$[13]$} \\
zot PCR & & $175-199$ \\
ZOT 1: TGG CTT CGT CTG CTG CCG GCG ATT & This paper \\
ZOT 2: CAC TTC TAC CCA CAG CGC TTG CGC & $1234-1258$ & This paper \\
Probes & $545-568$ & This paper \\
CT-int: CGT TAA TGA TGT ATT AGG GGC ATA & $1068-1087$ & This paper \\
ZOT-4: TCG TGG TCT ATG GGC GAC A & & \\
\hline
\end{tabular}




\section{Results}

A 564-bp fragment of gene ctxA and a 1083-bp fragment of gene zot, which were confirmed by hybridisation, were amplified from all 173 isolates. Regarding presence of genes $c t x A$ and $z o t$, there were no differences between the clinical isolates from Colombian patients and those from the environment.

Ribotyping of the isolates with $B g l$ I generated three patterns (Fig. 1). Pattern B5a was seen with 165 isolates. A new pattern, designated B20, was seen with six isolates from 1993. Another new pattern, designated B21a, was seen with two isolates obtained in April 1992 and February 1993 (Fig. 2). The geographic origin of the isolates is shown in Table 2 and Fig. 3.

\section{Discussion}

The South American cholera epidemic is considered to be the fourth period of the seventh pandemic. South America had been free from cholera since the end of the fifth pandemic which struck in the 1880s [19]. The finding of no differences between clinical and environment isolates confirms that environmental isolates are the result of faecal contamination of the environment. It is now admitted that $V$. cholerae $\mathrm{Ol}$ (CT positive) can become part of the aquatic flora and often in a physiological state which may make strains nonculturable but viable and potentially pathogenic

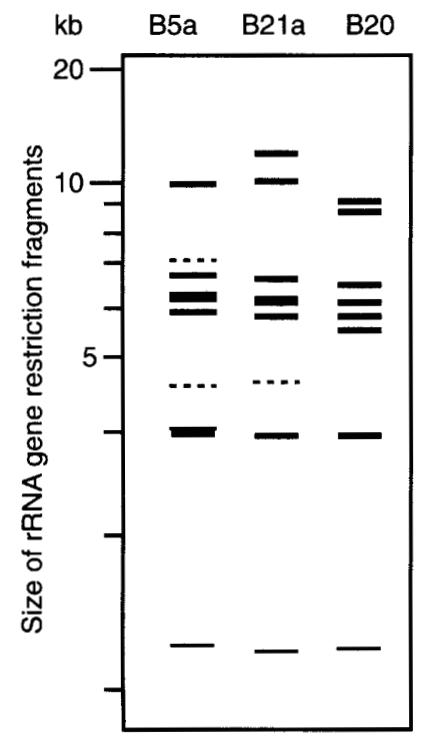

Fig. 1. Normalised graph showing migration patterns of rRNA gene restriction fragments of DNA from three $V$. cholerae $\mathrm{O} 1$ ribotypes from Colombia after $\mathrm{Bgl}$ cleavage and hybridisation with labelled E. coli $16+23 \mathrm{~S}$ rRNA.

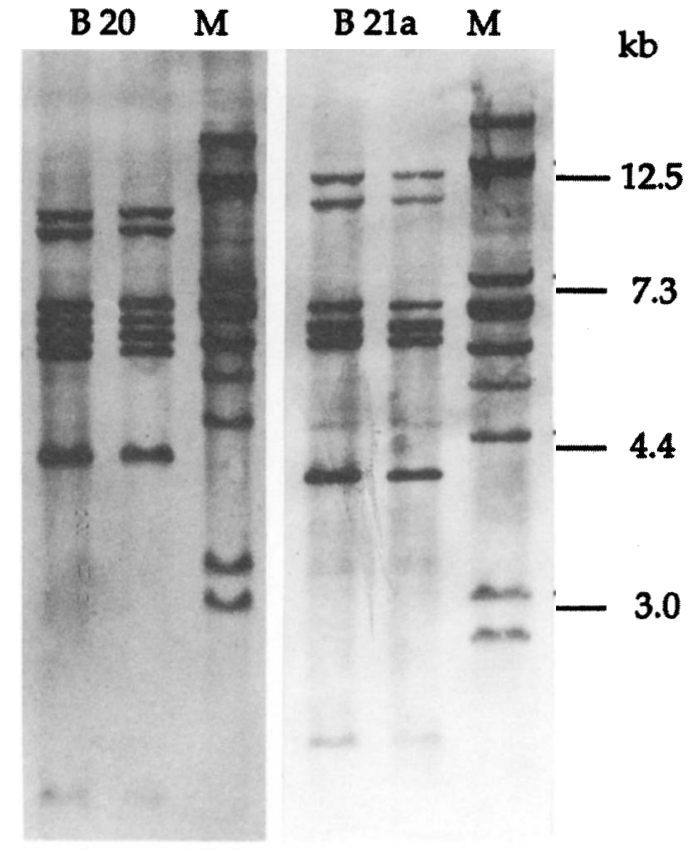

Fig. 2. Restriction fragment length polymorphism of rRNA genes after $B g l \mathrm{I}$ restriction for ribotypes B20 and B21a from $V$. cholerae strains isolated from Colombia. M, mol. wt marker - Citrobacter koseri strain 32 cleaved with $M l u \mathrm{I}$.

$[20,21]$. These strains cannot be isolated by conventional culture methods before reactivation inside the human gut [22]. The present study supports the findings of Johnson et al. [23] and Karasawa et al. [24] that all strains which harbour the $c t x$ gene also harbour the zot gene. Both toxins may act synergically in vivo. Other studies have shown that deletions could occasionally occur on the core region yielding strains possessing either $c t x$ or zot $[25,26]$. Our PCR results were also in agreement with the latex agglutination and ELISA tests done on 78 of the 173 strains to detect CT.

The three different ribotypes found suggest more than one introduction of cholera into Columbia. Ribotype B5a (isolated from 1991 to 1994) was predominant and was characteristic of Latin American isolates. It probably came from Equador or Peru [27]. It is noteworthy that the first case (1991) occurred on the Pacific coast near the border of Equador. This ribotype has now spread to most regions of Colombia (28 of 32 Colombian departments). Ribotype B20 was first found in the central region (Tolima department) in March 1993 and was found in April in the Pacific (Nariño) and Atlantic (Còrdova) regions. In June it was isolated in the department of Guajira (Atlantic region) and in San Andrès (islands in the Carribean sea). Ribotype B21a was isolated from two patients in April 1992 and February 1993 in the department of Atlàntico (Fig. 3). 
Table 2. Geographic distribution of $V$. cholerae ribotypes in Colombia

\begin{tabular}{|c|c|c|c|c|}
\hline \multirow[b]{2}{*}{ Region } & \multirow[b]{2}{*}{ Department $^{*}$} & \multicolumn{3}{|c|}{ Number of isolates with ribotype } \\
\hline & & B5a & B20 & B21a \\
\hline \multicolumn{5}{|l|}{ Pacific } \\
\hline & Cauca $(\mathrm{Cc})$ & 15 & 0 & 0 \\
\hline & Chocó (Ch) & 4 & 0 & 0 \\
\hline & Nariño (Na) & 11 & 1 & 0 \\
\hline & Valle (Va) & 19 & 0 & 0 \\
\hline \multicolumn{5}{|l|}{ Andine } \\
\hline & $\begin{array}{l}\text { Antioquia (An) } \\
\text { Bovacá (By) }\end{array}$ & $\begin{array}{r}10 \\
4\end{array}$ & $\begin{array}{l}0 \\
0\end{array}$ & $\begin{array}{l}0 \\
0\end{array}$ \\
\hline & $\begin{array}{l}\text { Boyacá (By) } \\
\text { Caldas (Cl) }\end{array}$ & 1 & 0 & 0 \\
\hline & Cundinamarca $(\mathrm{Cu})$ & 6 & 0 & 0 \\
\hline & Huila $(\mathrm{Hu})$ & 1 & 0 & 0 \\
\hline & Norte de Santander (NS) & 4 & 0 & 0 \\
\hline & Quindio $(\mathrm{Qu})$ & 1 & 0 & 0 \\
\hline & Risaralda (Ri) & 0 & 0 & 0 \\
\hline & Santander (Sa) & 4 & 0 & 0 \\
\hline & Tolima (To) & 5 & 1 & 0 \\
\hline \multicolumn{5}{|l|}{ Atlantic } \\
\hline & Atlántico (At) & 7 & 0 & 2 \\
\hline & Bolivar (Bl) & 7 & 0 & \\
\hline & Cesar $(\mathrm{Ce})$ & 2 & 0 & 0 \\
\hline & Córdova (Co) & 10 & 1 & 0 \\
\hline & Guajira $(\mathrm{Gj})$ & 4 & 1 & 0 \\
\hline & Magdalena (Ma) & 11 & 0 & 0 \\
\hline & San Andrés (SA) & 11 & 2 & 0 \\
\hline & Sucre $(\mathrm{Su})$ & 2 & 0 & 0 \\
\hline \multicolumn{5}{|c|}{ Amazonia } \\
\hline & Amazonas (Am) & 14 & 0 & 0 \\
\hline & Caquetá $(\mathrm{Cq})$ & 3 & 0 & 0 \\
\hline & Putumayo $(\mathrm{Pu})$ & 3 & 0 & 0 \\
\hline \multicolumn{5}{|c|}{ Orinoquia } \\
\hline & Arauca (Ar) & 3 & 0 & 0 \\
\hline & Casanare (Cs) & 1 & 0 & 0 \\
\hline & Guainía (Gi) & 0 & 0 & 0 \\
\hline & Guaviare (Gv) & 1 & 0 & 0 \\
\hline & Meta $(\mathrm{Me})$ & 1 & 0 & 0 \\
\hline & Vaupés (Vp) & 0 & 0 & 0 \\
\hline & Vichada (Vi) & 0 & 0 & 0 \\
\hline Total & & 165 & 6 & 2 \\
\hline
\end{tabular}

${ }^{*}$ Codes for Fig. 3 in parentheses.

Wachsmuth et al. [27] found that Latin American isolates of $V$. cholerae $\mathrm{O} 1$ belonged to a single ribotype (equivalent to ribotype 5 of Popovic et al. [9] and ribotype B5 of Koblavi et al. [8, 10]). Computeraided comparison of ribotypes allowed splitting pattern $\mathrm{B} 5$ in two $\mathrm{B} 5 \mathrm{a}$ and $\mathrm{B} 5 \mathrm{~b}$ [10]. The present results indicate that $95.4 \%$ (165 of 173) of Colombian isolates belong to ribotype B5a. This ribotype is the predominant ribotype of the seventh cholera pandemic in Africa and Asia [10].

The discovery of new ribotypes may mean either that different strains entered the country or that ribotype B5a underwent modifications. The localisation of the new ribotypes in time and space can be interpreted both ways: two entries of new strains of cholera, or two different DNA re-arrangements or mutations. Ribotype B20 is clearly different from B5a and is unlikely to have arisen from B5a. Since the completion of the present work, ribotype B21a has been recognised in recent strains from Turkey (1980),
Romania (1991-1994), Pakistan (1992), Lebanon (1993), Cambodia (1993) and Italy (1994) (unpublished data). None of the strains studied corresponded to $V$. cholerae $\mathrm{O} 1$ subtype Amazonia described by Coelho et al. [28], in the north of Brazil near the border with Colombia. In the present study, the 13 isolates from the Amazonian part of Colombia belonged to ribotype $\mathrm{B} 5 \mathrm{a}$.

The detection of new ribotypes in Colombia should stimulate interest in public health officials to survey the emergence of new $V$. cholerae strains. Molecular typing of $V$. cholerae strains, either performed locally or in an international centre, may help to quickly identify sources and confirm the vehicle of transmission in order to attempt control of the spread of the pandemic.

M. T. was supported by a fellowship from the 'Ministère des Affaires Etrangères' of the French government. 


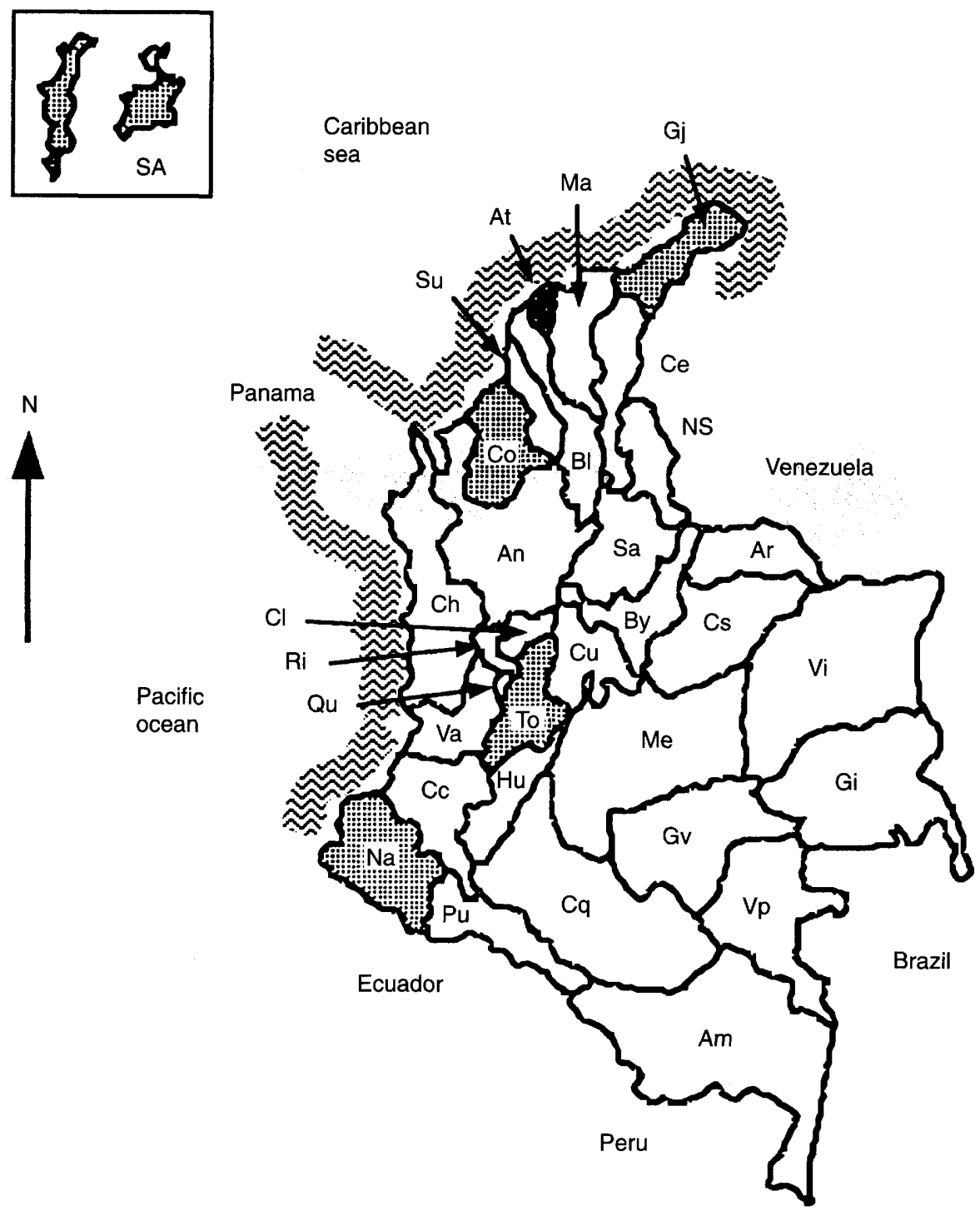

Fig. 3. Map of Colombia showing departments mentioned in Table 2. Departments where ribotypes B20 (鱼) and B21a (E) were found are indicated. Ribotype B5a was isolated in all departments except $\mathrm{Vp}, \mathrm{Gi}$, Vi and Ri. (Abbreviations for departments are given in Table 2.)

\section{References}

1. Glass RI, Libel M, Brandling-Bennett AD. Epidemic cholera in the Americas. Science 1992; 256: 1524-1525.

2. Castañeda E, Munoz N, Vargas CI, Escalante M, Galindo B, Castrillon L. Diagnostico bacteriologico del colera. Actividades del laboratorio nacional de referencia. Biomedica 1992; 12: 131-136.

3. Rivas F, De la Hoz F. Algunos aspectos clinicos del colera en el hospital San Andres de Tumaco. Biomedica 1992; 12: $102-108$.

4. Rivas Munoz, F. Descripcion de algunos aspectos epidemiologicos a un ano de diagnosticado el primer caso. Biomedica 1992; 2: 109-116.

5. Ministry of Health Communication. Colombia. 1995.

6. Grimont F, Grimont PAD. Ribosomal ribonucleic acid gene restriction patterns as potential taxonomic tools. Ann Inst Pasteur Microbiol 1986; 137B: 165-175.

7. Stull T, LiPuma JJ, Edlind TD. A broad-spectrum probe for molecular epidemiology of bacteria: ribosomal RNA. $J$ Infect Dis 1988; 157: 280-286.

8. Koblavi S, Grimont F, Grimont PAD. Clonal diversity of Vibrio

cholerae O1 evidenced by rRNA gene restriction patterns. Res Microbiol 1990; 141: 645-657.

9. Popovic T, Bopp C, Olsvik $\varnothing$, Wachsmuth K. Epidemiologic application of a standardized ribotype scheme for Vibrio cholerae O1. J Clin Microbiol 1993; 31: 2474-2482.

10. Koblavi S. Identification et typage moléculaire des Vibrionaceae. Thesis, University of Paris VII, March 1996. 1-385.

11. Baudry B, Fasano A. Ketley J, Kaper JB. Cloning of a gene (zot) encoding a new toxin produced by Vibrio cholerae. Infect Immun 1992; 60: 428-434.

12. Trucksis $M$, Galen $M$, Michalski J, Fasano A, Kaper JB. Accessory cholera enterotoxin (Ace), the third toxin of a Vibrio cholerae virulence cassette. Proc Natl Acad Sci USA 1993; 90: 5267-5271.

13. Fields PI, Popovic T, Wachsmuth K, Olsvik $\emptyset$. Use of polymerase chain reaction for detection of toxigenic Vibrio cholerae $\mathrm{O} 1$ strains from the Latin American cholera epidemic. $J$ Clin Microbiol 1992; 30: 2118-2121.

14. Fasano A, Baudry B, Pumplin DW et al. Vibrio cholerae produces a second enterotoxin, which affects intestinal tight junctions. Proc Natl Acad Sci USA 1991; 88: 5242-5246.

15. Farmer JJ, Hickman-Brenner FW. The genera Vibrio and Photobacterium. In: Balows A, Trüper HG, Dworkin M, Harder W, Schleifer K-H (eds) The prokaryotes, 2nd edn, vol III. New York, Springer-Verlag. 1992: 2952-3011.

16. Holmgren J, Svennerholm AM. Enzyme-linked immunosorbent assays for cholera serology. Infect Immun 1973; 7: 759-763.

17. Svennerholm AM, Holmgren J. Identification of Escherichia coli heat labile enterotoxin by means of a ganglioside immunosorbent assay (GM1-ELISA) procedure. Curr Microbiol 
1978; 1: 19-23.

18. Grimont F, Grimont PAD. Determination of rRNA gene restriction patterns. In: Howard J, Whitecombe DM (eds) Methods in molecular biology, vol 46: Diagnostic bacteriology protocols. Ottawa, Humana Press Inc. 1995: 181-200.

19. Kaper JB, Morris JG, Levine M. Cholera. Clin Microbiol Rev 1995; 8: 48-86.

20. Colwell RR, Huq A. Viable but nonculturable $V$. cholerae. In: Wachsmuth IK, Blake PA, Olsvik $\varnothing$ (eds) Vibrio cholerae and cholera: molecular to global perspectives. Washington, DC, 1994: American Society for Microbiology. 117-133.

21. Hasan JAK, Chowdhury MAR, Shahabuddin M, Huq A Loomis L, Colwell RR. Cholera toxin gene polymerase chain reaction for detection of non-culturable Vibrio cholerae $\mathrm{O} 1$. World J Microbiol Biotechnol 1994; 10; 568-571.

22. Colwell RR, Tamplin ML, Brayton PR et al. Environmenta aspects of Vibrio cholerae in transmission of cholera. In: Sack $\mathrm{RB}$, Zinnaki $\mathrm{R}$ (eds) Advances in research in cholera and related diarrheas. Tokyo, KTK Scientific. 1990: 327-343.

23. Johnson JA, Morris JG, Kaper JB. Gene encoding zonula occludens toxin (zot) does not occur independently from cholera enterotoxin genes (ctx) in Vibrio cholerae. $J$ Clin Microbiol 1993, 31: 732-733.

24. Karasawa T, Mihara T, Kurazono $\mathrm{H}$ et al. Distribution of the zot (zonula occludens toxin) gene among strains of Vibrio cholerae O1 and non-O1. FEMS Microbiol Lett 1993; 106: $143-145$.

25. Kurazono $\mathrm{H}$, Pal A, Bag PK et al. Distribution of genes encoding cholera toxin, zonula occludens toxin, accessory toxin, and El Tor hemolysin in Vibrio cholerae of diverse origins. Microb Pathog 1995; 18: 231-235.

26. Damian M, Koblavi S, Carle I et al. Molecular characterization of Vibrio cholerae $\mathrm{Ol}$ isolated in Romania. Res Microbiol (in press).

27. Wachsmuth IK, Evins GM, Fields PI et al. The molecular epidemiology of cholera in Latin America. I Infect Dis 1993; 167: $621-626$

28. Coelho A, Andrade JRC, Vicente ACP, Salles CA. New variant of Vibrio cholerae $\mathrm{O} 1$ from clinical isolates in Amazonia. $J$ Clin Microbiol 1995; 33: 114-118. 